\title{
連続受診者の冠危険因子に関する検討
}

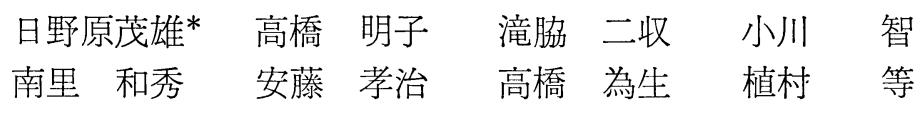

最近では健康教育あるいは一次予防への関心が著しく 高まっている。恐らくてれからは動脈硬化性疾患の一次 予防が健康教育の大きな目標になるものと予想される。 一次予防では個人毎の危険因子評価に基ずいた健康教育 が重要視されるが，コンピュータを備えた自動化総合健 診は一次予防を最む効率よく実施しうる施設である。乙 のため今後は評価した結果を理解し易い形で受診者に提 供して，健彮受款を健康教育あるいは予防に対してより 効果的に工夫することが重要と考えられる。

我々は従来より健診に指導表パターンと呼ぶ Coronary Risk Factor Pattern を作成し, 健診の各面接室の カラー端末に表示して健康指導を試みている。パターン は上半分の 6 項目が主に問猃によって得られる生活習 慣, 下半分が検査成績である。冠危険因子が無い人はパ ターンが大きくなり, 危険因子の多い人はパターンが縮 小するようにしてある。各項目毎に 4 段階に分け, リス クが無ければ外側の円にのって得点 1 点, リスクが増す につれ 2 点, 3 点, 4 点と次第に深くへこむようにし た。例えば 12 項目全てにリスクが無い場合は各項目 1 点となり, パターン得点は 12 点となる。今回はこの得 点を指標として総合健診の連続受診の有用性を検討し た。対象者は当センターの自動化総合健診を 1987 年の 1 月から 6 月の 6 力月間に受診した, 年齢が 30〜59 歳 の受診者のうち, 男性で, かつ前回との受診間隔が 1 年 半以内の連続受診者 1,587 名である。

なお，一部においては初回受晾者 897 名も対象として いる。はじめにパターンの上半分に相当する生活習慣 6 項目の個人毎の合計得点を累積度数分布図として, 連続 受効者の今回之前回, さらには初回受㡣者の 3 群で比較 した。生活習慣は初回受診者より連続受搒者の方が良好 で, 連続受診者のうちでは前回よりあ今回の方がさらに やや良好であった。次に得点が 1 点または 2 点, 即ちリ
スクが全く無いか僅かであった人々の比率を項目毎に分 けて，3群の百分率を比較した。3 群間にはほとんど差 が無く, 生活習慣は喫煙のみに初回受部者が悪い傾向が みられた。なお項目間には大きな差が認められた。しか し㭘査項目の累積度数分布図では連続受診者の方がむし ろ悪いという予想外の結果が得られた。従って, 次に連 続受診者でパターン得点が 4 点と最も悪く, ハイリスク であった人々の数を項目毎に検討した。連続受晾者の肥 満度に関するハイリスク者の数は前回が 157 名であった が，今回は 175 名に増加しており，単純に人数だけを比 較すると連続受搒者は効果が無かったような結果であっ た。しかし実際には前回がハイリスク者であった 157 名 は今回は 133 名に減少していた。要するに, 前回注意さ れたハイリスク者は改善してその数を減らしたが，逆に 前回ハイリスクでなかったものから 42 名のハイリスク 者が発生してしまい，合計では今回の方がハイリスク者 の数が多かった。次に高血圧のハイリスク者の数を比較 した。ハイリスク者は連続受喨により 23 名から 38 名に 増えていたが，てのうち前回がハイリスクであった受診 者は僅か 10 名に減っていた。代わりに前回がハイリス クでなかった受診者から, 前回以上の数のハイリスク者 が新たに発生していた。血清総コレステロールのハイリ スク者は前回と今回を単純に比較してあハイリスク者数 は改善していたが，内容的には指導された前回のハイリ スク者の $70 \%$ 以上に相当する 24 名の多数が改善し, 油 断して新たにハイリスク者之なった受彰者は 20 名と多 発していた。乙の他のトリグリセライド，尿酸，血糖值 などあコレステロールと同様の結果であった。

以上，指導表パターンの得点を用いて連続受竞の有用 性を検討した。総合健診の連続受診者にたいする指導は 生活習慣の改善ばかりでなく，検査成績の改善にも明ら かに有用であると考えられた。

\section{Coronary risk assesment for serial AMHTS examinees}

東海大学病院健診センター 